\title{
Air quality in relation to vehicular traffic-related gaseous emissions in two selected local government areas in south-western Nigeria
}

\author{
John O. Olamijulo, Godson R. E. E Ana \\ Department of Environmental Health Sciences,Faculty of Public Health, College of Medicine,University of Ibadan, Ibadan, Nigeria
}

Email address:

johnette07@yahoo.com(J. O. Olamijulo)

To cite this article:

John O. Olamijulo, Godson R. E. E Ana. Air Quality in Relation to Vehicular Traffic-Related Gaseous Emissions in two Selected Local Government Areas in South-Western Nigeria.International Journal of Environmental Monitoring and Analysis.

Vol. 1, No. 4, 2013, pp. 121-127.doi: 10.11648/j.ijema.20130104.12

\begin{abstract}
The aim of this study is to determine the concentration of traffic related air pollutants at major and busy road intersections in two Local Government Areas of Ibadan, Nigeria. A descriptive cross-sectional design was employed for the study. Ibadan North and North East Local Government Areas (LGAs) were purposely selected based on their high traffic density. Thirteen sampling points were randomly selected from the 18 major road intersections within the two LGAs. Levels of sulphur dioxide $\left(\mathrm{SO}_{2}\right)$, nitrogen dioxide $\left(\mathrm{NO}_{2}\right)$ and carbon monoxide $(\mathrm{CO})$ emissions in $(\mathrm{ppm})$ were measured using calibrated $\mathrm{SO}_{2} \mathrm{NO}_{2}$ and COmonitor. Traffic density was estimated via manual counting using tally system. Measurements were carried out in the morning (6am-8am), afternoon (12pm-2pm) and evening (4pm-6pm) for 12 weeks and results obtained were compared with WHO guideline limit. Data were analysed using descriptive statistics, ANOVA and Pearson correlation test at $5 \%$ level of significance. The mean gaseous emissions level were CO $(38.6 \pm 22.2 \mathrm{ppm}), \mathrm{SO}_{2}$ $(1.0 \pm 0.7 \mathrm{ppm}), \mathrm{NO}_{2}\left(0.2 \pm 0.1 \mathrm{ppm}\right.$. These values exceeded the $\mathrm{WHO}$ guideline limit for $\mathrm{CO}(10 \mathrm{ppm}), \mathrm{SO}_{2}(0.17 \mathrm{ppm}), \mathrm{NO}_{2}$ $(0.17 \mathrm{ppm})$. There was a significant difference in the mean gaseous emissions level across measurement periods of the day $(8 \mathrm{am}-10 \mathrm{am}, 12 \mathrm{pm}-2 \mathrm{pm}$ and $4 \mathrm{pm}-6 \mathrm{pm})(\mathrm{p}<0.05)$. There was a significant positive correlation between $\mathrm{SO}_{2}$ and traffic density $(\mathrm{r}=0.73)$. Gaseous emissions exceeded the WHO guideline limit for ambient conditions at the study locations. There is need for government to institute and enforce traffic emission control and air quality management programmes in Nigeria.
\end{abstract}

Keywords: Gaseous Emissions, Vehicular Traffic, Urban Communities, Ibadan

\section{Introduction}

Vehicle emissions represent a serious environmental health problem, which is expected to increase in significance as vehicle ownership increases globally [1]. Across the entire globe, motor vehicle traffic has increased tremendously. In 1950, there were about 53 million cars on the world's roads. On average, the fleet has grown by 9.5 million units per year over this period. Simultaneously, the truck and bus fleet has been growing by about 3.6 million vehicles per year.While the growth rate has slowed considerably in the industrialized countries, population growth and increased urbanization and industrialization are accelerating the use of motor vehicles elsewhere [2].

In urban areas mobile or vehicular pollution is predominant and significantly contributes to air quality problems. Road traffic produce volatile organic compounds, suspended particulate matter (SPM), oxides of sulphur (SOx), oxides of nitrogen (NOx), and carbon monoxide (CO), which causes adverse health effects on the exposed population. The particles emitted from the vehicular exhaust of more than 10micron size are held in upper respiratory tract and particles less than 10-micron size $\left(\mathrm{PM}_{10}\right)$ accumulates in the lung and produces respiratory abnormalities [3].

According to the United States Environmental Protection Agency (USEPA), vehicular emissions account for $51 \%$ of carbon monoxide, $34 \%$ of nitrogen oxides and $10 \%$ of particulate matter released each year in the United States. The United Nations estimated that over 600 million people in urban areas worldwide were exposed to dangerous levels of traffic-generated air pollutants [4]. Annually, air pollution accounts for an estimated 3 million deaths, which is $5 \%$ of the 55 million deaths that occur worldwide each year [5]. 
Traffic-related emissions are a complex mix of pollutants comprised of nitrogen oxides (including nitrogen dioxide), particulate matter, carbon monoxide, sulphur dioxide, volatile organic compounds, ozone, and many other chemicals such as trace toxics and greenhouse gases. The concentration of these pollutants varies both spatially (by location) and temporally by time $[6,7,8]$.

In developing countries, motorization growth has been largely unchecked by environmental regulations, creating high levels of pollution [9]. Traffic contributes more to ambient pollution in developing countries, accounting for upwards of $40-80 \%$ of $\mathrm{NO}_{2}$ and $\mathrm{CO}$ concentrations $[10,11$, 12]. This situation is alarming and is predicated on the poor economic disposition of developing countries. Poor vehicle maintenance culture and importation of old vehicles which culminate to an automobile fleet dominated by a class of vehicles known as "super emitters" with high emission of harmful pollutants, has raised high this figure of emission concentration. Furthermore, in developing countries the super emitters contribute about $50 \%$ of harmful emissions to the entire average emission [13].

In Nigeria much attention is given to general industrial pollution and pollution in oil industries, with little reference to damage of pollution caused by mobile transportation sources of air pollution $[14,15]$. The situation of increased pollution from mobile transportation source is on the increase in per capita vehicle ownership, thus resulting to high congestion on Nigeria city roads and increase in the concentration of pollutants in the air, consequently, increasing health risk on human population [16]. An assessment of the levels of the traffic related emissions would help guide policy formulation in this part of the globe.

Therefore in our study we set out to determine the levels of traffic-related gaseous emissionsat selected major road intersections in Ibadan North and Northeast Local Government areas in Ibadan, Oyo state, Nigeria.

\section{Materials and Methods}

We conducted this study in two Local Government Areas in Ibadan, Oyo State, Nigeria vizIbadan North and Northeast Local Government Areas.

\subsection{Study Area}

Ibadan is the capital city of Oyo State and the largest city in West Africa. It is located in the south-western region of Nigeria. It is $125 \mathrm{Km}$ inland from Lagos and is a prominent transit point between the coastal region and the areas to the north. It lies between latitude $7^{\circ}$ and $9^{\circ} 30^{\prime}$ east of prime meridian. Ibadan covers a land area of 12 kilometres radius. It has an altitude generally ranging from $152 \mathrm{~m}$ to $213 \mathrm{~m}$ with isolated ridges and peaks rising to $274 \mathrm{~m}$. Its population is estimated to be about 3.8 million according to the National Population Commission's 2006 census estimates. The principal inhabitants of the city are the Yorubas. [17].

\subsection{Selection of Sampling Point}

Simple random sampling was used to select thirteen road intersections from the major eighteen road intersections within the two Local Government Areas and these points served as the sampling locations (SL) of this study.

\subsection{Determination of Gaseous Samples}

Levels of traffic-related air pollutants levels comprising carbon monoxide (CO), Sulphur dioxide $\left(\mathrm{SO}_{2}\right)$ and Nitrogen dioxide $\left(\mathrm{NO}_{2}\right)$ were determined using extech carbon monoxide monitor model CO10, environmental sensors sulphur dioxide monitor model Z-1300 and environmental sensors nitrogen dioxide monitor model Z1400 respectively. The measurements were conducted three times a day (8am-10am, 12pm-2pm, and 4pm-6pm) during the study periodfollowing WHO guidelines (June 2011 August 2011).Measurements were carried out at thirteen sampling locations (SL1-SL13). The data obtained were recorded daily (three times a week for each sampling location) for three months and prior calibration of the monitors was done according to standard procedures. The gas monitors were calibrated on the field in a Ziploc polythene bag which was free of the target gas. The gas monitors were hand held at the sampling locations and stretched at arm's length to determine the ambient levels of the pollutants. Measurements were taken at each sampling location and the means were computed.

\subsection{TrafficDensity Estimation}

Traffic density was estimated via manual counting using the tally system. Three research assistants were recruited to count the number of cars, buses, bikes and trucks that pass through the sampling points for a period of 15 minutes and this was used to estimate the hourly traffic density. Traffic count was conducted three times a day, morning (6am $7 \mathrm{am})$, afternoon $(12 \mathrm{pm}-1 \mathrm{pm})$ and evening $(4 \mathrm{pm}-5 \mathrm{pm})$. An observational checklist was used to describe the characteristics of the study location.

\subsection{Statistical Analysis}

All the data obtained were subjected to descriptive statistics and ANOVA all at 5\% level of significance. ANOVA was used to test for any significant differences in the means of the $\mathrm{CO}, \mathrm{NO}_{2}$ and $\mathrm{SO}_{2}$ at the different periods of measurementwhile Spearman rank correlation test was used to determine the strength of the linear relationship between traffic count and concentration of $\mathrm{CO}, \mathrm{NO}_{2}$ and $\mathrm{SO}_{2}$ at the selected study locations.

\section{Results and Discussion}

Table 1 show the geographical coordinates of the selected road intersections in the two LGA's which served as the sampling locations for this study. 
Table 1.Geographical Coordinates Of Selected Sampling Locations

\begin{tabular}{|c|c|c|c|c|}
\hline Location & Area & Latitude & Longitude & Elevation \\
\hline L1 & Mokola & $\begin{array}{l}\mathrm{N} 07^{0} \\
24.020^{\prime}\end{array}$ & $\begin{array}{l}\text { E } 003^{0} \\
53.387^{\prime}\end{array}$ & $195 \mathrm{~m}$ \\
\hline L2 & Mokola & $\begin{array}{l}\mathrm{N} 07^{0} \\
24.044^{\prime}\end{array}$ & $\begin{array}{l}\text { E } 003^{0} \\
53.409^{\prime}\end{array}$ & $200 \mathrm{~m}$ \\
\hline L3 & Sango & $\begin{array}{l}\mathrm{N} 07^{0} \\
25.157^{\prime}\end{array}$ & $\begin{array}{l}\text { E } 003^{0} \\
53.774,\end{array}$ & $190 \mathrm{~m}$ \\
\hline L4 & Sango & $\begin{array}{l}\text { N } 07^{0} \\
25.394\end{array}$ & $\begin{array}{l}\text { E } 003^{0} \\
53.908^{\prime}\end{array}$ & $215 \mathrm{~m}$ \\
\hline L5 & $\begin{array}{l}\text { University } \\
\text { of Ibadan }\end{array}$ & $\begin{array}{l}\mathrm{N} 07^{0} \\
26.461\end{array}$ & $\begin{array}{l}\text { E } 003^{\circ} \\
54.400^{\prime}\end{array}$ & $230 \mathrm{~m}$ \\
\hline L6 & Bodija & $\begin{array}{l}\mathrm{N} 07^{0} \\
25.022\end{array}$ & $\begin{array}{l}\text { E } 003^{0} \\
54.704^{\prime}\end{array}$ & $237 \mathrm{~m}$ \\
\hline L7 & Bodija & $\begin{array}{l}\mathrm{N} 07^{0} \\
25.850^{\prime}\end{array}$ & $\begin{array}{l}\text { E } 003^{0} \\
54.769^{\prime}\end{array}$ & $231 \mathrm{~m}$ \\
\hline L8 & $\begin{array}{l}\text { Osuntokun } \\
\text { avenue }\end{array}$ & $\begin{array}{l}\mathrm{N} 07^{0} \\
25.044^{\prime}\end{array}$ & $\begin{array}{l}\text { E } 003^{0} \\
54.591\end{array}$ & $214 \mathrm{~m}$ \\
\hline L9 & $\begin{array}{l}\text { Awolowo } \\
\text { avenue }\end{array}$ & $\begin{array}{l}\mathrm{N} 07^{0} \\
25.022\end{array}$ & $\begin{array}{l}\text { E } 003^{0} \\
54.661\end{array}$ & $205 \mathrm{~m}$ \\
\hline L10 & $\begin{array}{l}\text { Total } \\
\text { Garden }\end{array}$ & $\begin{array}{l}\mathrm{N} 07^{0} \\
23.908^{\prime}\end{array}$ & $\begin{array}{l}\text { E } 003^{0} \\
54.542^{\prime}\end{array}$ & $178 \mathrm{~m}$ \\
\hline L11 & Agodi gate & $\begin{array}{l}\mathrm{N} 07^{0} \\
23.721\end{array}$ & $\begin{array}{l}\text { E } 003^{0} \\
55.136^{\prime}\end{array}$ & $246 \mathrm{~m}$ \\
\hline L12 & Idi ape & $\begin{array}{l}\mathrm{N} 07^{0} \\
24.171\end{array}$ & $\begin{array}{l}\text { E } 003^{0} \\
55.541\end{array}$ & $252 \mathrm{~m}$ \\
\hline L13 & Oremeji & $\begin{array}{l}\mathrm{N} 07^{0} \\
22.842,\end{array}$ & $\begin{array}{l}\text { E } 003^{0} \\
56.035^{\prime}\end{array}$ & $220 \mathrm{~m}$ \\
\hline
\end{tabular}

\subsection{General Information about the Sampling Locations}

Table 2 shows the onsite observations related to air quality in the selected sampling locations. Majority of the sampling locations were situated in areas with high commercial activity though there were no industries located in the study sites.

Activities around the study sites include bush burning, construction processes e.t.cthere were also dumpsites and generators in some study sites. Due to the presence of a cemetery at location 3 , the bushes in the cemetery were regularly cleared and burnt to beautify it and this accounted for generation of some air pollutants. Location 4 is situated around Sango market while locations 6 and 7 are sited within the popular Bodija market. Usually, large volume of waste is generated from markets and due to the inefficiency in the disposal of waste in this markets, large expanse of land develop into dumpsite. Burning of waste in this dumpsite also contributed to the poor air quality in these areas. Generator emission was also a major menace at location 5 because of its closeness to the main campus of the University of Ibadan. Due to the erratic supply of electricity in Nigeria, most commercial ventures around the University depend mainly on generators.

In addition, the result of the observational checklist shows that majority of the sampling locations were sited on tarred roads

Table 2. General information about sampling locations

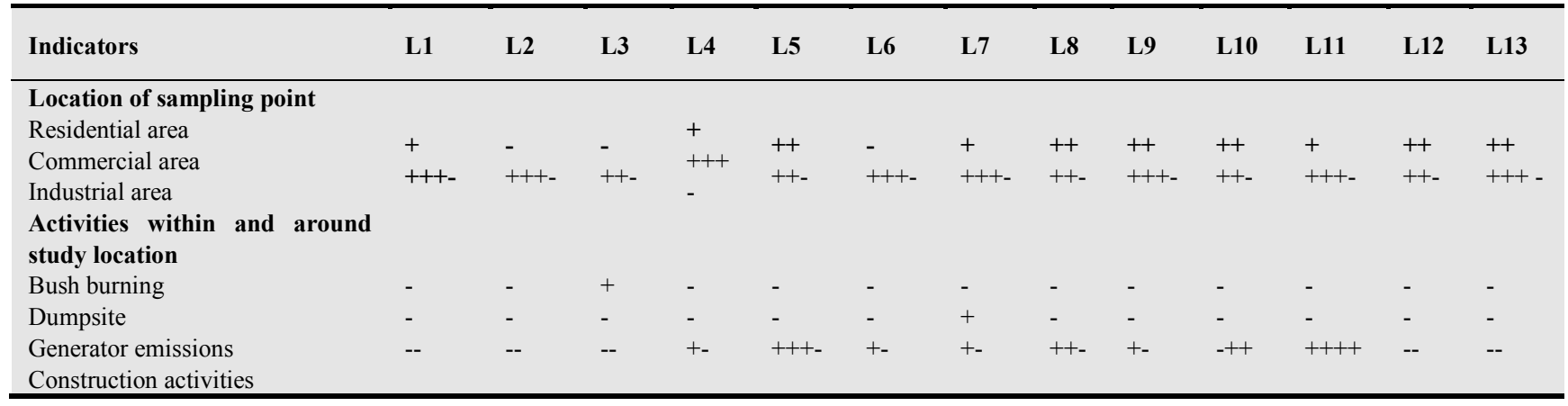

Key: +++ Highly present ++ moderately present + present - absent

\subsection{Sulphur Dioxide Concentration $\left(\mathrm{SO}_{2}\right)$}

Figure 1 display the weekly mean concentration of sulphur dioxide $\left(\mathrm{SO}_{2}\right)$ measured at the different sampling location during the morning (8am - 10am), afternoon $(12 \mathrm{pm}-2 \mathrm{pm})$ and evening sampling hours respectively in comparison with the WHO guideline limit.Levels of $\mathrm{SO}_{2}$ at location 1 peaked in the evening with concentration of $1.24 \mathrm{ppm}$. This was higher than the WHO guideline limit of $0.17 \mathrm{ppm} . \mathrm{SO}_{2}$ concentrations recorded at location 11 during morning, afternoon and evening sampling periods showed that location 11 recorded the highest $\mathrm{SO}_{2}$ levels in all the 13 sampling points in the two Local Governments. Concentrations were highest in the evening period and were all above WHO guideline limit of $0.17 \mathrm{ppm}$. It was observed that most of the concentrations of $\mathrm{SO}_{2}$ recorded during the evening period were higher than the morning concentrations by a factor of 2 .

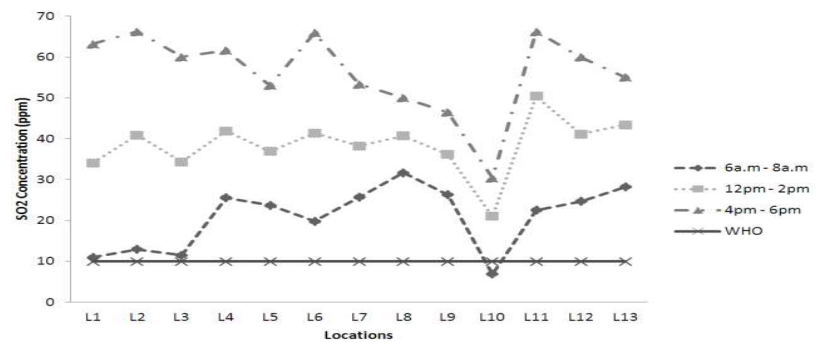

Figure 1. Weekly mean $\mathrm{SO}_{2}$ concentration for all the thirteen locations at different sampling time interval 


\subsection{Nitrogen Dioxide $\left(\mathrm{NO}_{2}\right)$ Concentration}

Levels of $\mathrm{NO}_{2}$ at location 1 were high in the morning and afternoon but peaked in the evening with concentrations of $0.04 \mathrm{ppm}, \quad 0.12 \mathrm{ppm}$ and $0.20 \mathrm{ppm}$ respectively and they were all higher than the guideline limit of $0.17 \mathrm{ppm}$ except in the morning and afternoon hours. Concentrations of $\mathrm{NO}_{2}$ in the morning hours in all the sampling locations were all below the guideline limit of $0.17 \mathrm{ppm}$ (See figure 2). The least concentration of $\mathrm{NO}_{2}$ was recorded at location 5 with concentration ranging from $0.04 \mathrm{ppm}$ in the morning to $0.12 \mathrm{ppm}$ in the evening period. Concentration of $\mathrm{NO}_{2}$ during the afternoon and the evening hours were below the guideline limit. There was a significant difference in the concentrations of $\mathrm{NO}_{2}$ determined in each of the sampling points at different sampling periods $(\mathrm{p}<0.05) . \mathrm{NO}_{2}$ concentrations during the morning and evening periods peaked at location 12 while $\mathrm{NO}_{2}$ concentration peaked during the afternoon period at location 11. All evening concentrations were higher than the afternoon and morning concentrations.

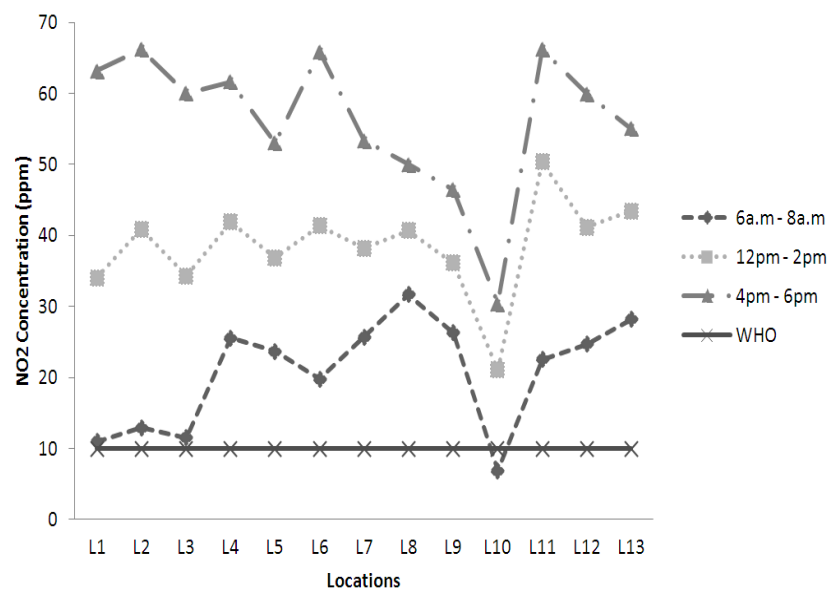

Figure 2.Weekly mean $\mathrm{NO}_{2}$ concentration for all the thirteen locations at different sampling time interval

\subsection{Carbon (II) Oxide (CO) Concentration}

$\mathrm{CO}$ concentrations recorded in the morning periods in all the 13 sampling points in the 2 LGAs were higher than the WHO guideline limit except at location 10. All evening concentrations were higher than the afternoon concentrations and were all above WHO guidelines limit of $10 \mathrm{ppm}$. CO concentration at location 4 was at its peak in the evening period $(61.6 \mathrm{ppm})$ while during the morning period, CO concentration was higher at this location compared to location 11.CO concentration was highest in the morning period at location 8 while it was lowest at location 10.The least concentration of $\mathrm{CO}$ was recorded at location 10 with concentration ranging from $6.9 \mathrm{ppm}$ in the morning to $30.4 \mathrm{ppm}$ in the evening period and they were all above the WHO guideline limit. There was a significant difference in the concentration of $\mathrm{CO}$ determined at each of the sampling points at different sampling periods $(p<0.05)$.

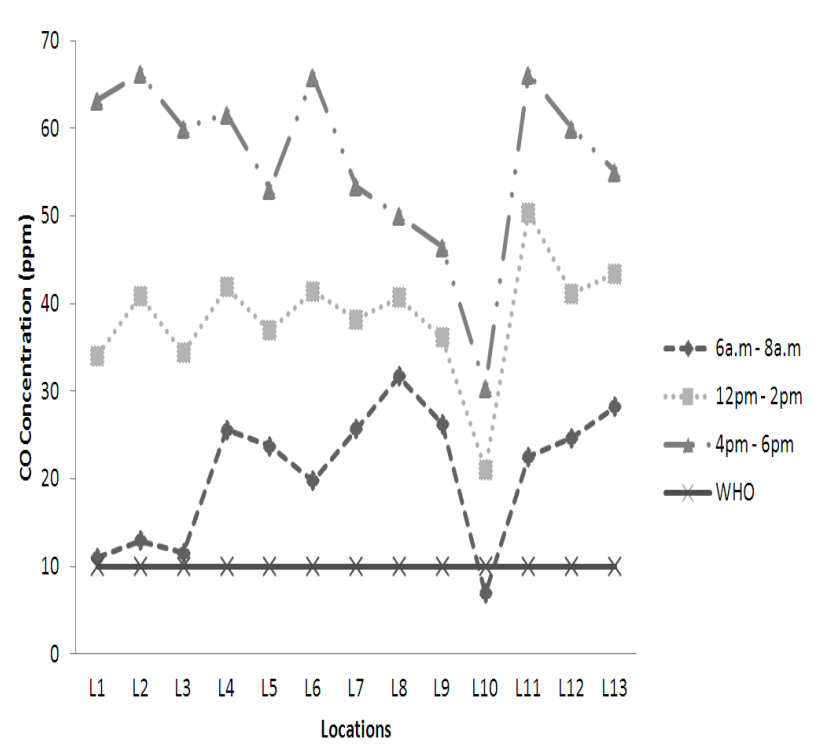

Figure 3. Weekly mean CO concentration for all the thirteen locations at different sampling time interval

\subsection{Traffic Density}

A significant difference in the number of vehicles across the sampling period was observed for all the sampling locations. The weekly mean traffic count recorded in the morning (6am $-7 \mathrm{am})$, afternoon $(12 \mathrm{pm}-1 \mathrm{pm})$ and evening $(4 \mathrm{pm}-5 \mathrm{pm})$ across all the 13 sampling points are presented in table 6.0.Generally, location 12 had the highest traffic count/hr $(270,136)$ while location 5 had the lowest traffic count/hr (197,382). Location 9 had the highest number of cars/hr $(169,394)$ while location 1 had the lowest number of cars/hr (80274). On the other hand, the highest number of buses/hr was recorded at location 4 $(34,564)$ while the lowest was recorded at location 12 $(18,276)$.Furthermore, location 4 had the highest number of trucks/hr (4578); total number of trucks at location 12 was 3436 while location 8 had the lowest number of truck $/ \mathrm{hr}$ (2082). In addition the total number of bikes $/ \mathrm{hr}$ (a combination of total number of motorcycles and tricycles) was on the high side in locations 1- 4 as well as locations 11-13. Location 11 had the highest number of bikes $/ \mathrm{hr}$ $(144,550)$ and this was higher than the corresponding number of cars/hr $(57,170)$ at this location while the lowest number of bikes/hr was recorded at location $5(45,552)$.

\subsection{Relationship between Traffic Related Air Pollutants and Traffic Count}

Figures 4 to 6 show the outcome of the Pearson correlation test between the concentrations of sulphur dioxide, nitrogen dioxide, carbon (II) oxide and traffic count. A strong positive correlation was observed between concentration of sulphur dioxide and traffic density ( $\mathrm{rs}=$ 0.73). Traffic count was found to be positively correlated with the concentration of carbon (II) oxide ( $r$ = 0.79 ) while a positive correlation also existed between traffic count and the concentration of nitrogen dioxide $(\mathrm{rs}=0.60)$. 
Table 6. Weekly mean traffic density for the sampling locations

\begin{tabular}{|c|c|c|c|c|c|c|c|c|c|c|c|c|}
\hline \multirow[t]{2}{*}{$\begin{array}{l}\text { Samplinglocati } \\
\text { ons }\end{array}$} & \multicolumn{3}{|l|}{ Cars } & \multicolumn{3}{|l|}{ Buses } & \multicolumn{3}{|l|}{ Trucks } & \multicolumn{3}{|c|}{ Bikes } \\
\hline & $\begin{array}{l}\text { Mornin } \\
\mathrm{g}\end{array}$ & $\begin{array}{l}\text { Afterno } \\
\text { on }\end{array}$ & Evening & $\begin{array}{l}\text { Morn } \\
\text { ing }\end{array}$ & $\begin{array}{l}\text { Afterno } \\
\text { on }\end{array}$ & Evening & $\begin{array}{l}\text { Morn } \\
\text { ing }\end{array}$ & $\begin{array}{l}\text { Afterno } \\
\text { on }\end{array}$ & Evening & $\begin{array}{l}\text { Morn } \\
\text { ing }\end{array}$ & $\begin{array}{l}\text { Afterno } \\
\text { on }\end{array}$ & $\begin{array}{l}\text { Evenin } \\
\mathrm{g}\end{array}$ \\
\hline L1 & 655 & 1390 & 1652 & 252 & 354 & 317 & 39 & 53 & 55 & 665 & 1718 & 2424 \\
\hline L2 & 1038 & 2118 & 2057 & 334 & 429 & 390 & 41 & 66 & 57 & 1007 & 1973 & 2461 \\
\hline L3 & 1021 & 1985 & 2139 & 313 & 339 & 426 & 46 & 39 & 48 & 831 & 1600 & 1801 \\
\hline L4 & 1180 & 1843 & 2246 & 454 & 643 & 516 & 49 & 79 & 63 & 1164 & 1753 & 1996 \\
\hline L5 & 1674 & 1742 & 1945 & 581 & 533 & 425 & 38 & 44 & 51 & 563 & 651 & 685 \\
\hline L6 & 1524 & 1781 & 2150 & 373 & 419 & 335 & 27 & 96 & 51 & 652 & 850 & 866 \\
\hline L7 & 2091 & 2237 & 2460 & 345 & 44 & 301 & 22 & 44 & 39 & 957 & 632 & 722 \\
\hline L8 & 1958 & 2183 & 2422 & 274 & 320 & 316 & 20 & 26 & 41 & 1004 & 900 & 1201 \\
\hline L9 & 2392 & 2209 & 2457 & 412 & 320 & 396 & 28 & 39 & 28 & 1010 & 916 & 965 \\
\hline L10 & 496 & 1470 & 1674 & 360 & 361 & 414 & 26 & 49 & 37 & 387 & 1150 & 1283 \\
\hline L11 & 555 & 943 & 885 & 343 & 478 & 423 & 26 & 37 & 48 & 1699 & 2121 & 2203 \\
\hline L12 & 1886 & 2023 & 2096 & 300 & 431 & 324 & 38 & 48 & 58 & 1161 & 2010 & 2038 \\
\hline L13 & 2003 & 1865 & 1864 & 231 & 323 & 282 & 29 & 451 & 43 & 1283 & 1908 & 1811 \\
\hline
\end{tabular}

*Bikes: Motorcycles \& Tricycle

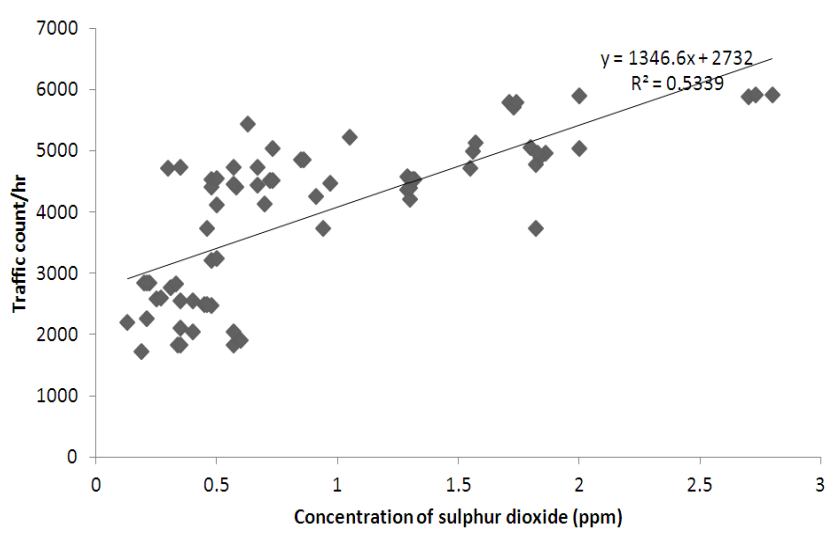

Figure 4. Relationship between traffic count/hr and concentration of sulphur dioxide

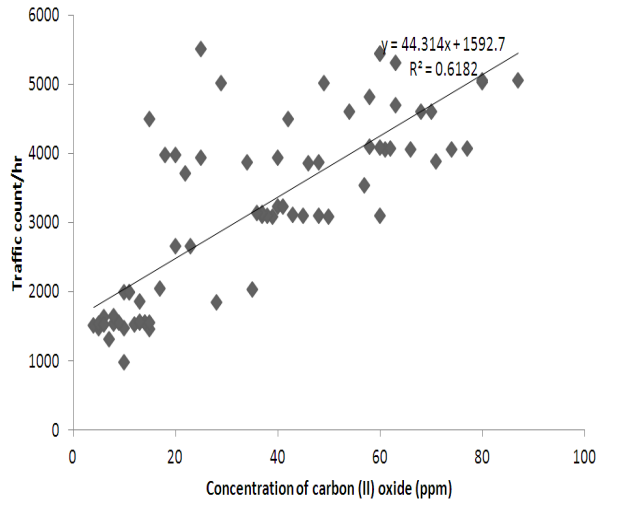

Figure 6. Relationship between traffic count/hr and concentration of carbon (II) oxide

\section{Discussion}

The UNFPA reports that the global urban population reached $50 \%$ in 2008 and is expected to increase to $60 \%$ by 2030 [18]. This increase will be particularly pronounced in developing countries, in which $80 \%$ of the urban population will be living in 2030 . The rise in urban

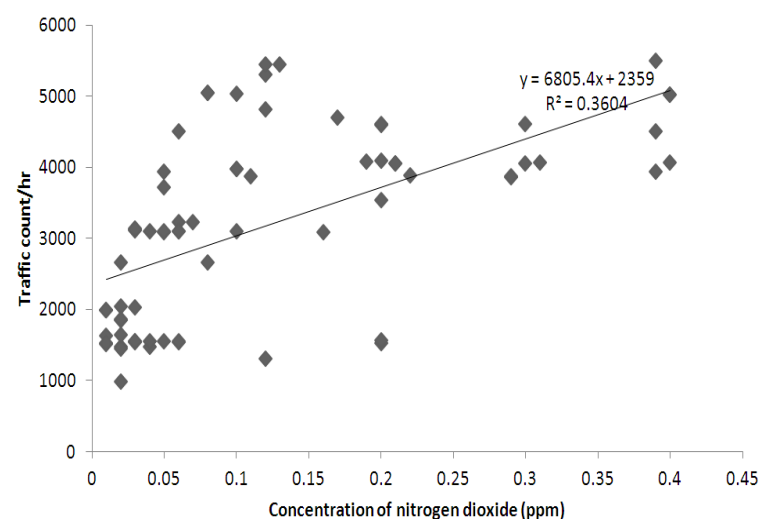

Figure 5. Relationship between traffic count/hr and concentration of nitrogen dioxide

population has a fourfold increase in the number of motorized vehicles in cities by 2050 , aggravating the hazard even in countries with overall low motorization rates [19].Studies have shown that the population of Nigeria increase geometrically making traffic-related air pollution an important public health problem in Nigeria. In this study, the concentration of traffic related air pollutants at major and busy road intersections was assessed at baseline to provide a basis for future risk assessment and possible interventions.

The weekly mean traffic count at study location showed that location 12 had the highest traffic count/hr. This is as a result of its proximity to the popular spare-parts market at Agodi gate and also due to the presence of banks in the area. This is consistent with the findings of a study carried out by [16] in Calabar, Cross-River state who reported that the high traffic volume in one of its study site was as a result of its closeness to a popular market in the town. Concentration of nitrogen dioxide, sulphur dioxide and carbon monoxide in almost all the study locations were above the WHO guideline limit and this can be attributed to the high traffic volume at these study locations. Studies 
conducted by $[10,11,12]$ revealed that traffic contributes more to ambient pollution in developing countries, accounting for $80 \%$ of nitrogen dioxide and carbon monoxide concentrations.

Furthermore, recent Government policies in Nigeria have increased the importation of old vehicles by $30 \%$ with the extension of the age of used motor vehicles from 10 years to 15 years from the year of manufacture. This coupled with poor vehicle maintenance culture in Nigeria has resulted in automobile fleets highly dominated by old vehicles that produce tonsof emissions composed ofhazardous pollutants. This is in line with the findings of a study carried out in Mexico City in 1999 by United Nations Environmental Programme (UNEP). They reported that old vehicles are responsible for $90 \%$ of hydrocarbons and carbon monoxide emissions as well as $80 \%$ of nitrogen dioxide emissions in the country [13]

The weekly mean concentration of carbon monoxide recorded between the hours of $6 \mathrm{a} . \mathrm{m}-8 \mathrm{a} . \mathrm{m}$ in all the sampling locations were all above the WHO Guideline Limitsfor air quality (10ppm) except at location 10 which had concentration of $6.88 \pm 2.27 \mathrm{ppm}$. Carbon monoxide concentration recorded in all locations between the hours of 12 p.m - 2p.m (afternoon) were all above the WHO guideline limit and it peaked at location 11 (50.38 \pm $19.53 \mathrm{ppm})$. This was five-fold higher than the WHO guideline limit. Also, between the hours of 4p.m - 6p.m (evening), carbon monoxide concentrations in all study locations were above the guideline limit and peaked at location $2(66.23 \pm 31.48 \mathrm{ppm})$ which is six fold higher than the guideline limit. This is at variance with the results obtained by [20] who reported a concentration of $28 \mathrm{ppm}$ for $\mathrm{CO}$ in Hong kong, China during rush hours and [21] who also reported a $\mathrm{CO}$ concentration of 12.3 in the central city of Tehran, Iran.

The high level of carbon monoxide recorded in this study could have resulted from the high traffic count recorded at each sampling locations. This was further explained by the significant positive correlation observed between concentration of carbon monoxide at study locations and traffic count.

The weekly concentration of sulphur dioxide $\left(\mathrm{SO}_{2}\right)$ recorded in all study locations between the hours of 6a.m 8a.m (morning) were all above the WHO guideline limit of $0.17 \mathrm{ppm}$ reaching its peak at location $9(0.85 \pm 0.13)$ and which was 5 times higher than the WHO guideline. $\mathrm{SO}_{2}$ concentration recorded in all study locations between the hours of 12p.m -2p.m (afternoon) and 4p.m - 6p.m (evening) were all above the morning concentrations and equally higher than guideline limit with concentrations at some locations as high as $2.07 \pm 0.64 \mathrm{ppm}$ which is 12 fold higher than the guideline limit. This is in line with the findings of a study by [22], who found out that the concentrations of $\mathrm{SO}_{2}$ and $\mathrm{NO}_{2}$ were maximal in the afternoon and minimal during the morning period. However, the variations of these parameters may be attributed to the dynamics of the atmospheric boundary layer and associated convective turbulence, which extensively mixed and redistributed pollutants to a greater vertical extent.

The weekly mean concentration of Nitrogen dioxide $\left(\mathrm{NO}_{2}\right)$ recorded in all study locations between the hours of (6a.m - 8a.m) were all above the WHO guideline (0.17ppm) except locations 1, 3, 5 and 10. On the other hand, concentration of $\mathrm{NO}_{2}$ recorded in all the study locations between the hours of $(12 \mathrm{p} . \mathrm{m}-2 \mathrm{p} . \mathrm{m})$ and $(4 \mathrm{p} . \mathrm{m}-6 \mathrm{p} . \mathrm{m})$ were higher than the guideline with concentrations as high as $0.23 \mathrm{ppm}$ which is two folds higher than the guidelines.

The high concentration of $\mathrm{NO}_{2}$ can also be attributed to the high traffic density at the sampling locations. This is evident by the significant positive correlation between $\mathrm{NO}_{2}$ concentration and traffic count. A similar study in Tartu, Estonia conducted by [23] showed the ambient level of $\mathrm{NO}_{2}$ increased from $50 \%$ to $100 \%$ in several monitoring stations according to the yearly monitoring data from 1994 to 1999 and this increase was caused by increasing number of vehicles. Furthermore, transport emission accounted for $52 \%$ of the total $\mathrm{NO}_{2}$ emission in the city.

\section{Conclusion}

This study determined the concentration of traffic related air pollutants at major and busy road intersections in two Local Government Areas of Ibadan, Nigeria.

Our findings revealed that the ambient concentrations of the traffic related air pollutants measured at the different road intersections within the two Local Government Areas were significantly higher than the WHO guideline limit by several folds.

We observed a significant positive relationship between the concentration of traffic-related air pollutants and traffic count at the selected road intersections.

Air pollution at these road intersections constitutes a major public health hazard. Therefore, we recommend that a holistic approach should be adopted in combating this environmental nuisance. This includes provision of mass transit buses to reduce the number of private vehicles plying the road, use of blended fuels, formulation and implementation of policies aimed at improving traffic flow. This would significantly reduce the levels of these pollutants in the Local Government Areas.

\section{Acknowledgement}

The authors are grateful to the Master of Public Health Students in the Department of Environmental Health Sciences at the College of Medicine, University of Ibadan, who participated as field assistants during the study. The technical support from relevant departments within and outside at the University is also gratefully acknowledged. 


\section{References}

[1] Moen, E., 2008. Vehicle Emissions and Health Impacts in Abuja,

Nigeria.http://www.who.int/entity/quantifying_ehimpacts/co untryprofilesebd.xls. Retrieved 2010-08-29

[2] Schwela, D., Olivier, Z., Schwela, P., 1997. Motor vehicle air pollution public health impact and control measures. World Health Organization. Division of Operational support in environmental health, Geneva, Switzerland.

[3] Ingle, S.T., Bhushan, G., Pachpande, Nilesh D. Wagh, Vijaybhai S. Patel and Sanjay B. Attarde, 2005. Exposure to vehicular pollution and respiratory impairment of Traffic policemen in Jalgon city, India. Journal of Industrial Health; 43: 656-662.

[4] Boudaghpour,S., Alireza, J., 2009. Investigation of the effect of outlet pollutants of cement production industries around Tehran and approaches to control and eliminate pollutants. International Journal of Physical Sciences Vol. 4, Pp 486-495.

[5] Cacciola, R.R., Sarva, M., Polosa, R., 2002. Adverse respiratory effects and allergic susceptibility in relation to particulate air pollution: flirting with disaster. Allergy; 57: 281-6.

[6] De Paula Santos, U., Braga, A., Giorgi, D., Pereira, L., Grupi, C., Lin, C., 2005. Effects of air pollution on blood pressure and heart rate variability: a panelstudy ofvehicular traffic controllers in the city of Sao Paulo, Brazil. Eur Heart J; 26:193-200.

[7] Dragonieri, S., Musti, M., Izzo, C., Esposito, L.M., Barbaro, M., Resta, O., 2006. Sputum induced cellularity in a group of traffic policemen. Sci Total Environ; 367:433-436.

[8] Tamura, K., Jinsart, W., Yano, E., Karita, K., Boudoung, D., 2003. Particulate air pollution and chronic respiratory symptoms among traffic policemen in Bangkok.Arch Environ Health; 58:201-207.

[9] Han, X., Naeher, L., 2006. A review of traffic-related air pollution exposure assessment studies in the developing world.Environment International. 32(1): 106120.

[10] Fu, L., 2001. Assessment of vehicle pollution in China. Journal of the Air and Waste Management Association. 51(5): 658-68.

[11] Goyal, S., 2006. Understanding urban vehicular pollution problem vis-a-vis ambient air quality - case study of a megacity (Delhi, India). Environmental Monitoring and

[12] Abbaspour, M., Soltaninejad, A., 2004. Design of an environmental assessment model on the effect of vehicle emission. International Journal of Environmental Science Technology. 1(1): 27-38.

[13] Brunekreef, B., 2005. Out of Africa, Occupation and Environmental Medicine. 62:351-352.

[14] Faboya, O.O., 1997. "Industrial pollution and waste management" pp 26-35 in AkinjideOsuntokun (ed), Dimensions of Environmental problems in Nigeria, Ibadan Davidson press.

[15] Magbagbeola, N. O., 2001. "The use of economic instruments for industrial pollution abatement in Nigeria: Application to the Lagos Lagoon", In Nigeria Economic Society, Natural Resources Use, University of Ibadan, Ibadan, Nigeria, pp. 535-556

[16] Abam, F.I.,Unachukwu, G.O.2009. Vehicular emissions and air quality standards in Nigeria'. European Journal of Scientific Research. ISSN 1450-216X Vol.34 No.4, pp.550560. http://www.eurojournals.com/ejsr.htm

[17] National Population Commission, 2006. The breakdown of the National and State Provisional Population Totals 2006 Census. Federal Republic of Nigeria Official Gazette. No.24, Vol.94. Published by the Federal Government Printer, Lagos, Nigeria.

[18] UNFPA., 2007."State of world population: unleashing the potential of urban growth" $<$ http://www.unfpa.org/swp/2007/english/introducti on.html>.

[19] World Bank. "World Bank East Asia and the Pacific Urban Business Directions".2004. Washington, DC: World Bank, East Asia Department.

[20] Chow, W.K., Chan, M.Y., 2003. Field measurement on transient carbon monoxide levels in vehicular tunnels. Build Environ; 38:227-36.

[21] Abdollahi M., Zadparvar L., Ayatollahi B., Baradaran M., Nikfar S., HastaieP, et al., 1998. Hazard from carbon monoxide poisoning for bus drivers in Tehran, Iran. Bull Environ ContamToxicol;61:210-5.

[22] Ragini, N., Chandrashekara, M. S., Nagaiah, N.,Paramesh, L., 2009. "Study of atmospheric electrical conductivity, $\mathrm{SO}_{2}$, $\mathrm{NO}_{2}$, aerosols SPM $(>10 \mu)$ and RSPM $(<10 \mu)$ in Mysore city, India", Toxicology and Environmental Chemistry, Vol. 91 No. 4, pp. $605-609$

[23] Kimmel V, Kaasik M., 2003. Assessment of urban air quality in south Estonia by simple measures. Environ Model Assess; $8: 47-53$. 